\title{
Вопросы педагогики
}

\section{Валентин СЕРЕДА}

\section{ГАРМОНИЧЕСКАЯ ЗАДАЧА И ЕЕ РОЛЬ В МУЗЫКАЛЬНОМ РАЗВИТИИ СТУДЕНТОВ}

ГАРМОНИЯ - явление универсальное. Ее можно обнаружить и в разнообразных явлениях природы, и в обшественной жизни: в любом виде деятельности человека, в различных видах искусства. И во всех своих проявлениях гармония существует не в качестве некоего изолированного элемента, взаимодействующего с другими, с такими же независимыми элементами, а лишь как результат, возникающий (или не возникаюший) от такого взаимодействия.

Музыкальные словари дают определение гармонии как «стройности», «соразмерности», «единства противоположностей». Если для философов такие определения могут оказаться достаточными, то для рядового педагога-теоретика они слишком абстрактны, лишены конкретности. Как использовать эти критерии в оџенке представленных студентами работ? Как находить и оџенивать в них эти качества?

Приходится искать иные пути, чтобы приблизить философски-обобщенные определения к практике, изобретать «самодеятельные» определения, помогающие педагогу в его работе.

ГАРМОНИЯ В МУЗЫКЕ — также не изолированный элемент музыкальной ткани, наряду с ритмом, метром, фактурой, мелодией. Гармония возникает (или не возникает) как результат взаимодействия әлементов музыкальной ткани.

Однако не всякое взаимоотношение элементов в музыке, не всякое одновременное сочетание звуков, не любое совместное звучание голосов, не всякая последовательность созвучий могут порождать гармонию. Как и в жизни, гармония в музыке рождается в таком взаимодействии элементов музыкального языка, в результате которого каждый из них приобретает новые иенностные свойства.

Так, любой звук приобретает новые свойства, попадая в состав аккорда: он становится аккордовым тоном (примой, терџией и т. д.) задержанием, проходящим, вспомогательным звуком или предъемом, становится тоном побочным или внедряюшимся, наделяя своим присутствием другие тоны вертикали новыми свойствами и приобретая их от взаимодействия с остальными тонами.

Одноголосная мелодия приобретает новый смысл, когда к ней добавляется сопровождение, раскрывающее ее скрытые свойства.

ᄉюбой аккорд выявляет разнообразные оттенки своих функџий в условиях логически организованной гармонической последовательности. Сравнения можно продолжить.

Однако, работа с задачей очень важна, поскольку она может послужить основой для осознания способности музыки передавать суть жизни - ее движение, развитие, преобразование, обновление. Решение задач предполагает освоение логического принџипа раз- 
вертывания мелодических линий, в котором, как в фокусе, сходятся все основные факторы, формируюшие проџесс:

- синтаксическое членение - распределение синтаксических единиџ по их масштабу, а также смысловому, интонаџионному весу. Возникающее в проџессе развития дробление компенсируется последующим суммированием, как правило, построенным на синтезе интонаџий;

- интонаџионный сюжет - последовательность различных әлементов темы, их взаимное родство или контраст, порождаюшее интонационную драматургию мелодии;

- метроритмические структуры, возникаюшие на уровне тактов, группируюшие доли тактов внутри них, а также способствуюшие разделению тяжелых и легких тактов.

Следует различать бессмысленный набор ступеней лада, организованный лишь механическим ритмом и вставленный в определенный тональный звукоряд, и логически организованный проџесс интонаџионного развертывания, отличающй настоящую музыку. Первый лишь внешне сохраняет видимость смысловой структуры (примеры такого рода легко найти в некоторых дидактических материалах, предлагаемых ученикам в качестве диктантов или гармонических задач). Второй отличает настоящую музыку от ее механической подделки (примеры в огромном количестве можно найти именно в живой музыке).

Другая основа гармонического ошушения коренится в характере отношения голосов, составляющих гармоническую ткань.

Замечательна заслуга А.Ф. Мутли, раскрывшего природу этого явления [см.: 5]. Согласно его идее, голоса музыкальной ткани разделяются на гармонические и мелодические (в нашем понимании - тематические).

Задача голосов гармонических — обеспечивать соединения соседних аккордов согласно әлементарным нормам голосоведения. Именно к таким голосам относятся строгие правила голосоведения, на которых воспитывают студентов.

Голоса тематические участвуют, каждый по-своему, в развертывании тематического проиесса.

К ним относятся:

- ведущй̆ голос, т. е. голос, излагающий основной тематический материал. Он обладает структурной замкнутостью и интонаџионной завершенностью, основанной на развитии и завершении исходного тематического ядра. Именно ведуший голос может служить представителем произведения, именно его вспоминает слушатель, если хочет вспомнить конкретное произведение;

- имитируюший голос, воспроизводящий точно или свободно материал ведущего голоса и тем самым подчеркивающй его особую значимость;

- контрапунктирующий голос, противопоставленный ведущему по различным признакам (ритмическому и мелодическому рисунку, жанровой природе, образному строю). Служит ярким фоном для ведущего голоса и способствует многогранности музыкального образа, но, как правило, не обладает в полной мере смысловой и композиџионной оформленностью (в противном случае возникает контрапунктическое соединение нескольких равных тем);

- удвоение ведушего (или любого другого) голоса в определенный интервал или созвучие, благодаря чему его рисунок приобретает большую рельефность и становится более заметным в гармонической ткани; 
- противодвижение - воспроизведение рисунка ведущего голоса (или другого

из тематических голосов), одновременно с ним в противоположном движении;

- педаль - выдержанный голос или созвучие. Его неподвижность служит ориентиром для оџенки меняющегося рисунка, ритма и синтаксиса остальных голосов.

Интонаџионная связь голосов, имеющих различные тематические функиии, придает дополнительный смысл каждому из них и служит одной из основ гармонического ощушения в музыкальной ткани.

Имитируюшио голос, так же как и противодвижение, продолжает и усиливает образ, возникший в ведушем голосе. Удвоение рисунка ведущего (или любого другого из тематических голосов) делает его более рельефным. Педаль служит прекрасным ориентиром для оџенки мелодического рисунка любого из голосов. Контрапунктируюший голос создает контраст к интонаџиям ведушего голоса, подчеркивая его индивидуальный рисунок.

Если слой гармонических голосов интонаџионно не связан с голосами тематическими, он утрачивает самостоятельный художественный смысл и становится лишь инструментом создания механической основы движения. Зато проникновение интонаџий из голосов тематических в слой голосов гармонических объединяет их в обшей гармонии.

Задача включения интонаџий главного голоса в сопровождающие всегда должна стоять перед педагогом, работающим с гармонической задачей, поскольку даже в темах, использующих только главные трезвучия, попытка решения этой задачи активизирует фантазию и изобретательность.

\section{Средства, составляющие основу гармонической ткани}

1. Гармоническая горизонталь - ощушения временного потока, который создается гармонией. Она включает:

- Систему гармонических функџй̈, которые обеспечивают чередование движения и покоя: тоника как выражение состояния покоя, доминанта - движение $\kappa$ тонике, субдоминанта - движение от тоники.

Каждая из гармонических функџий может иметь разную степень активности. Так, тоника может быть закрытой - выражать состояние полного покоя, не ожидающего продолжения, и открытой - предполагаюшей дальнейшее движение. Столь же разнообразно могут быть представлены и остальные элементы гармонического проџесса.

- Систему мелодических функџй̈ - отношение мелодических устоев и подкрепляющих их неустоев внутри каждой мелодической линии.

Мелодические функџии своим действием могут преобразовывать смысл привычных гармонических структур, варьировать и изменять их функџии. Благодаря мелодическим функџиям гармонии могут обогашаться различного рода побочными тонами, становятся возможными диссонирующие созвучия в качестве главных гармонических тоник.

2. Гармоническая вертикаль - красочная составляющая гармонии. Ее образует:

- Структура созвучий. Единство гармонического колорита или колористический контраст разных разделов формы выступают в качестве самостоятельного выразительного и формообразуюшего средства, которое проявляется в отборе вертикальных структур определенного интервального строения и порождаемого им гармонического колорита. 
- Модальная основа гармонической ткани - важнейший формообразуюший и выразительный фактор гармонии. Пентатоническая, строго-диатоническая, условнодиатоническая, хроматическая, целотоновая основа музыкальной ткани, звукоряды октавные и неоктавные, их смена, переход одной основы в другую также служат фактором, создаюшим и гармоническую горизонталь или гармонический колорит произведения или его части.

- Модальные позиџии ступеней лада, интервалов и аккордов, создающие многоџветие гармонического материала в музыкальном произведении.

- Модальная природа гармонической вертикали - отражение в интервальной структуре аккордов интервального состава опорного звукоряда. Каждому типу звукоряда соответствует свой тип созвучий ${ }^{1}$.

Существуют созвучия пентатонические, аккорды строгой диатоники (бестритоновые септ- и нонаккорды), гармонии условной (альтераџионной) диатоники, включающие в свой состав ее гармонические элементы в виде «характерных» интервалов или аккордов, целлттоновые созвучия, гармонии, отражающие в своем составе интервальное строение «симметричных» звукорядов. Смена этих типов созвучий создают условия для движения и обновления музыкального образа.

- Система вертикальных функџий - особый тип функџиональных отношений, возникающий внутри гармонического комплекса.

Сушествование вертикальных функций особенно актуально для многозвучных гармоний, способных расслаиваться на более простые части - «субаккорды», каждый со своим, местным основным тоном, между которыми возникают конкурентные отношения, и создается особое ошушение сложного музыкального пространства.

Ошушение временного потока, организованного по законам музыкальной хогики, стало одним из открытий теоретиков тональной $\mathrm{cucmeмы,} \mathrm{хотя} \mathrm{ко} \mathrm{времени} \mathrm{теоретического} \mathrm{осозна-}$ ния на практике эта система существовала уже не менее сотни лет.

Тональная система выступает в качестве естественной основы гармонии классической музыки. Однако ею далеко не исчерпываются выразительные возможности современного музыкального языка. Уже давно стала очевидной необходимость освоения новой модальности - выразительных свойств, сушественно обогативших язык европейской гармонии. Начавшись еще с эпохи венских классиков, этот проџесс активно продолжался в музыке XIX и XX веков ${ }^{2}$.

Решением гармонических задач не исчерпываются все формы воспитания гармонического мышления.

Весьма полезной при воспитании гармонического мышления является система творческих заданий, помогающая студентам выходить за рамки привычной тональной логики. К сожалению, она явно недостаточно разработана в наших учебниках и учебных пособиях.

\footnotetext{
${ }^{1}$ Принџип соответствия интервальной структуры созвучий и интервального состава модальной основы (строения опорного звукоряда) постепенно приходит на смену прежней, казалось бы, незыблемой терџовой основе строения аккордов, превратив ее лишь в частный случай строения вертикали.

${ }^{2}$ Природа модальной системы и основы модальной техники изложены в работах автора настоящей статьи [7-9].
} 
Не меньшую роль могли бы сыграть и задания по анализу гармонической ткани (особенно сочинений XIX и XX веков, принџипы музыкального языка которых далеко выходят за пределы тональной логики). Крайне полезны и многочисленные виды упражнений на фортепиано, если они развивают воображение и фантазию студентов, а не закрепляют практически уже «умершие» формы тональных стереотипов.

В данном случае мы пытаемся сформулировать методику решения гармонических задач, которая способствует развитию творческого мышления и приближает сознание студентов к постижению логики тональной системы, включая те ее формы, которые дожили до наших дней.

К сожалению, на протяжении последних десятилетий в традиџионном курсе гармонии закрепился другой, явно неплодотворный, путь. Здесь мелодия, предлагаемая для гармонизаџии, заранее сконструирована для подбора и подстановки известных гармонических оборотов - проходяших, вспомогательных, прерванных, кадансовых, фригийских, которые и предлагается распознать студентам. При этом в таких мелодиях могут отсутствовать даже начатки интонаџионной логики, связывающей соседние гармонические обороты.

Результат решения таких задач напоминает сборку «пазлов», где соседние обороты механически соединены в соответствии с действующими нормами голосоведения, причем часто вопреки музыкальной логике. Такой подход не имеет отношения к практическому освоению гармонии, необходимому как для творчества, так и для исполнительства, поскольку он не дает понимания логики проџесса и опирается только на «юридическую» основу формальных правил голосоведения.

Школьные правила гармонии фиксируют лишь внешние проявления музыкальной логики. В этих правилах свойствами нормы наделяются «среднеарифметические», «статистически наиболее вероятные» последовательности звуковых элементов и способы их связи, а все нетипичные, не отвечаюшие среднестатистическим показателям связи звуков исключаются из обихода и даже объявляются запретными, разрешенными лишь в отдельных случаях, как исключение. При этом в качестве распространенного объяснения такому факту нередко применяется тезис: «Это невозможно объяснить, это надо просто запомнить».

На практике џелью традиџионного курса гармонии в музыкальном училище (колледже) нередко становится лишь подготовка студентов к экзаменам — и выпускным, и приемным на следуюшиі этап музыкального образования. Требования этих экзаменов проводятся по давно установившимся и много лет не пересматриваемым требованиям. Главное в решении таких задач - не допустить запретных приемов последования и соединения аккордов и подобрать к элементам данной мелодии подходяџие гармонические обороты.

В итоге курс гармонии базируется на нескольких стойких мифах, говорящих о «дозволенном» и «недозволенном» в курсе гармонии.

К числу этих мифов относятся следующие утверждения:

- любая задача должна начинаться с тоники;

- недопустимо начало с кадансового квартсекстаккорда;

- нельзя брать субдоминанту после доминанты;

- доминантсептаккорд в основном виде можно применять только в каденџии;

- невозможно движение голосов параллельными октавами и квинтами (исключая «моџартовы» квинты и октавы крайних голосов в заключительной каденџии); 
- юбой аккорд (даже стоящий на самой короткой и последней доле такта - должен иметь «правильное» расположение и «правильное» удвоение ${ }^{1}$.

Все эти и подобные им другие мифы - результат искаженных представлений о смысле гармонии в музыке, основанных лишь на привычке к практике, сложившейся за многие десятилетия. Они являются следствием отсутствия не только научных представлений, но лишены даже опоры на здравый смысл.

В итоге на место объективной оџенки качества решенной задачи приходит чистый субъективизм, а часто и произвол: все решает вкус преподавателя, отдающего предпочтение одним приемам перед другими, непривычными или незнакомыми ему, и при этом не соответствуюшими традиџиям «школы», которую педагог прошел (по принџипу «нас так не учили»).

Положение, сложившееся в этом направлении музыкальной педагогики, нельзя считать нормальным. Чем, кроме произвола, можно объяснить факт, что приемы, разрешенные в одних учебных заведениях, запрешены в других? Более того, нередко то, что допускает один педагог, запрешается ученикам из параллельной группы. Ученику приходится изучать не гармонию, а вкус и пристрастие определенного педагога или традиџии, сложившиеся в определенном учебном заведении.

Главным условием при этом остается анализ интонаџионного содержания голосов тематических, с учетом их жанровой основы и образного строя. В существуюшей методике курса гармонии абсолютно упускается из вида, что гармоническая ткань не «забор» из аккордов, соединенных по правилам голосоведения, а, прежде всего, ансамбль мелодий, каждая из которых имеет не только гармоническую, но, в большей или меньшей мере, и тематическую функцию.

Не учитывая этого обстоятельства, реальная практика преподавания гармонии становится полностью оторванной от художественного смысла упражнений. Ни в одном учебнике гармонии не содержится установки на сознательное выделение, противопоставление и связь стадий движения и покоя, разграничения и взаимодействия тяжелых и легких тактов, анализа синтаксического строения мелодии, определения логики ее интонаџионного содержания. В результате нередко студенту (а то и педагогу) непонятен смысл механизма, обеспечивающего самое ценное свойство музыки - ее возможность передавать развитие мысли, чувства, движение человека в танце, нарастание и убывание звуковой массы.

Качество мелодий, представленных для гармонизаџии - личная заслуга авторов, результат их творческой и педагогической одаренности.

Из тех учебных пособий, в которых гармонические задачи в полной мере отвечают критериям музыкальности, можно назвать «Практические задания к курсу гармонии» коллективный труд педагогов Института им. Гнесиных [3]. Этим критериям отвечают и многие мелодии из «Бригадного» учебника [2], особенно из его второй части, а также из задачников А.Н. Мясоедова [4], В. Беркова и А. Степанова [1], А.Ф. Мутли [6].

\footnotetext{
${ }^{1}$ Существует несколько «запрещенных» вариантов расположения аккордов, имеющих в педагогическом фольклоре особые клички (например, секстаккорды «дубовый» или «липовый» - с октавой средних голосов между квинтовыми или основными тонами). Такие секстаккорды непременно вычеркиваются из учебных работ, несмотря на то, они имеют достаточно широкое применение в музыке.
} 
Однако нередко педагоги вынуждены обрашаться к пособиям, материал которых ориентирован на особый стиль «школьной музыки». Стиль этот трудно назвать музыкальным, поскольку он рассчитан лишь на формальное усвоение условных правил, а дидактические материалы слишком далеко от норм, принятых в живой музыке.

Следует задуматься, каким образом приблизить методику решения гармонических задач к реальной музыкальной логике, как добиться того, чтобы в ней сохранилось самое џенное свойство музыкального языка - его способность передать суть жизни ее движение, обновление, преобразование. Для этого необходимы учебные материалы, позволяюшие четко видеть все факторы движения, ощушать различие «веса» тактов («тяжелых» и легких») и долей такта, спеџифику ритмического наполнения крупных и мелких синтаксических построениі. Не менее важно и четкое ощущение интонационного «сюжета» мелодии и интонаџионных связей всех голосов гармонической ткани.

Необходимость выявлять интонаџионный сюжет нередко упирается в неясность критериев определения џезуры. Некоторые учебники относят к таким критериям вполне случайные признаки - такие, как пауза, устойчивый звук, долгая нота. Эти признаки могут сопутствовать џезуре (а могут и не сопутствовать), но не они ее создают. Наиболее бесспорными признаками џезуры являются, по мнению автора этих строк, два момента:

1. Начало повтора мелодического материала;

2. «Точка покоя» - звук или доля такта, на которую приходится последняя гармоническая функция во фразе (с учетом проходящих, вспомогательных звуков или задержаний).

Если повтор начинается вслед за «точкой покоя», возникает глубокая и бесспорная џезура. Но точка покоя способна создать џезуру даже и между интонаџионно контрастными элементами темы, которые стремятся слиться с одну структуру в силу своего различия, если их не разделяет точка покоя.

В представленных ниже вариантах решения гармонических задач используется следующая система обозначения граниџ фраз и точек покоя:

- граниџы фраз обозначены фразировочными лигами;

- «точки покоя» обозначены знаком «П» («покой», как читалась эта буква в славянской азбуке);

- знак «точка покоя», заключенный в скобки, отмечает мелодические устои, которые следует преодолеть средствами гармонии, ритма и голосоведения;

- пунктирными скобками отмечены имитаџии элементов ведущего голоса в сопровождающих голосах.

Обозначения фраз и точек покоя отражают мнение автора о синтаксическом строении мелодий, в соответствии с ними строится и гармоническое оформление. Естественно, что возможны и другие варианты фразировки, соответствующие другому представлению о жанровой природе и образному строю мелодий, и для их оформления возможны другие варианты гармонизаџии. Важно, чтобы при этом сохранялась логическая связь всех элементов фактуры, и решение не сводилось к подбору стандартных гармонических оборотов под стандартные мелодические фигуры.

В композиторской практике сложилось различное отношение к гармониям, стояшим на сильной и слабой долях такта (а также в тяжелых и легких тактах). Если гармонии сильных долей џенятся за полноту, свежесть, новизну фонизма и его стилистическую оправданность, то вертикальные структуры на слабых долях џенится за убеди- 
тельное и интонаџионно оправданное мелодическое движение, обеспечивающее их связь с опорными гармониями. Поэтому в реальных музыкальных произведениях на слабых долях и легких тактах нередки различные отступления от строгих школьных норм расположения и удвоения. Здесь могут образовываться аккорды неполные или с «неправильным» удвоением, созвучия неопределенной структуры и гармонической функџии, и даже кластеры, если достигается главный смысл - связь их с опорными гармониями на основе осмысленных мелодических линий.

Для достижения свободы голосоведения необходимо преодолеть сложившуюся традиџию, согласно которой на начальном этапе курса гармонии используются мелодии, состояшие только из аккордовых звуков, и лишь изредка допускаются неаккордовые звуки, отмеченные звездочками. Между тем, целый год, в течение которого студенты проходят курс элементарной теории, они имеют достаточно возможностей, чтобы разобраться в природе неаккордовых звуков и научиться самостоятельно их находить, определять и использовать в своих творческих работах, а впоследствии - в решении гармонических задач.

При этом важно в сопровождающих голосах избегать использования случайных, «одноразовых» интонаций, не имеюших отзвука в ведушем голосе или в соседних фразах.

Особый вопрос возникает об удвоениях в трезвучиях и их обрашениях. В действующих пособиях и учебниках нет четкой позиџии по этому вопросу. Почему в главных трезвучиях следует удваивать основной тон, в секстаккордах — приму и квинту, а в трезвучии VI ступени или секстаккорде II ступени «допускается» удвоение терџии?

Между тем, удвоение основного тона в тонике или субдоминанте - вовсе не непреложный закон. В музыке немало примеров, где в тонике удвоены терџии или квинты, более того, тоника усложнена побочными тонами. Это меняет смысл тонической функџии, преврашает ее из «зоны покоя» в элемент движения, делает «открытой», устремленной к продолжению и развитию, чем отличает ее от стандартного удвоения примы в тонике «закрытой», не стремящейся к продолжению.

Более радикальный ответ на смысл и необходимость удвоения в аккордах связан с пониманием модальных позищий тонов аккорда. Наиболее спокойно звучат гармонии, в которых удваиваются нейтральные ступени лада - те, что образуют с тоникой чистые интервалы. В гармониях тоники, субдоминанты и доминанты это основные тоны, в трезвучиях и секстаккордах VI и III ступеней - терџии.

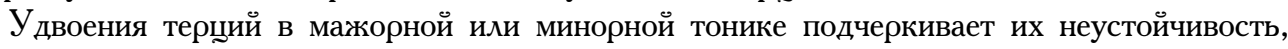
так как это усиливает роль модально активных ступеней - высоких в мажоре и низких в миноре. То же и в трезвучиях субдоминанты и доминанты. Значительно реже встречаются гармонии с удвоением звуков доминантового или субдоминантового тритона, полярных по своим модальным позиџиям.

Предлагаемые ниже варианты решений в ряде случаев не совпадают с обозначенными в условиях задач гармоническими средствами, не всегда учтены и обозначенные звездочками неаккордовые звуки. Как правило, здесь не учитывались и лиги, предлагаемые некоторыми авторами задач. В большинстве случаев они обозначают скорее приемы артикуляџии, а не логическую фразировку, и иногда просто могут сбить с толку ученика, решаюшего задачу.

Как правило, на начальном этапе курса гармонии предпочтение отдается голосам гармоническим. Тематические функџии сопровождающих голосов в таких задачах поневоле сглажены, и могут на протяжении задачи меняться, преврашаясь из удвоения 
в противодвижение, останавливаясь на время в качестве педали или преврашаясь в имитирующий голос.

Что касается контрапунктирования, то возможность для него предоставляется в более сложных темах курса гармонии. Однако уже на ранних стадиях курса гармонии применение неаккордовых звуков представляется настоятельно необходимым, что вытекает из осознанного отношения к средствам, обеспечиваюшего движение в музыке. Неаккордовые звуки на слабой доле такта (в основном, вспомогательные и проходяшие) дают возможность добиться связности тяжелых и легких тактов и преодолеть возникающие ритмические застои в точках покоя. Что касается задержаний, то они часто являются средством для построения кадениионных рифм.

Важно лишь, чтобы структура ведущего и других голосов не напоминала «буриме» бессмысленный набор интонаџий, связанных лишь размером и тональностью (что нередко можно увидеть в сравнительно новых учебниках, появившихся в последнее время).

По мере прохождения курса мелодический материал, предлагаемый для гармонизаџии, становятся интонаџионно богаче и допускает более активное использование отдельных элементов ведущиего голоса для обогаџения интонаџионного материала сопровождаюџих голосов. В каждой новой теме, изучаемой в курсе гармонии, появляются свои собственные установки, связанные с расширением возможностей применяемых средств. Многие из них касаются обогашения структуры вертикали благодаря внедрению неаккордовых звуков или альтераџй. Здесь особенно важна модальная природа аккордов - связь структуры вертикали с интервальным строением модальной основы.

Фактура гармонической ткани задач ориентирована на приниипь хорового письма. Из этого вытекает обязательное требование пропевания условия задачи для определения ее структуры, выявления зон движения и покоя ${ }^{1}$. Пропевание каждого написанного голоса помогает оџенить его мелодическую выразительность и построить интонаџионное связь с другими голосами. Итоговым способом оџенки качества выполненных работ является их хоровое исполнение.

Содержашиеся в настоящей публикаџии образџы решений гармонических задач, основаны на материале, заимствованном из пособий, изданных в разные годы. В отборе материала для данной работы автор руководствовался собственным представлением о музыкальных достоинствах мелодий, предлагаемых для гармонизаџии.

Вполне естественно, что каждый из представленных образџов решения не является единственно возможным, «правильным», не допускающим иного взгляда и подхода. Конечно, и другой взгляд, если он четко сформулирован и опирается на иные свойства музыкального материала, другую стилистику, иное понимание роли гармонии, может дать другой конечный результат. Единственное, что недопустимо - это ставить нормы школьной гармонии выше норм, сложившихся в художественной практике.

Гармоническая задача предназначена служить моделью реальной музыкальной ситуации. Любой педагог, ведущий курс гармонии и, тем более, проводящий прием-

\footnotetext{
${ }^{1}$ Польза от такого пропевания намного превосходит по своему результату анализ мелодии «глазами»: то, что пропето, осознается как «голос души», а то, что лишь увидено как «неумелые попытки ума».
} 
ные экзамены, должен видеть в представленной задаче именно модель живой музыки, а не набор стандартных оборотов, в сушности, повторяюших уже «умершие» стереотипы.

$$
* * *
$$

\section{ОБРАЗЦЫ РЕШЕНИЯ ГАРМОНИЧЕСКИХ ЗАДАЧ}

\section{Трезвучия главных ступеней}

\section{Пример 1 [3, с. 5]}

«Вольности», допушенные в данном варианте решения, позволяют выявить тематические функџии голосов путем ритмического контраста и интонаџионной связи, а также разграничения «веса» тяжелых и легких тактов. В $1-2$, а также в 5-6 тактах в партии тенора возникает имитация ведушего голоса, ради чего потребовалось отступление от строгих норм расположения аккордов.

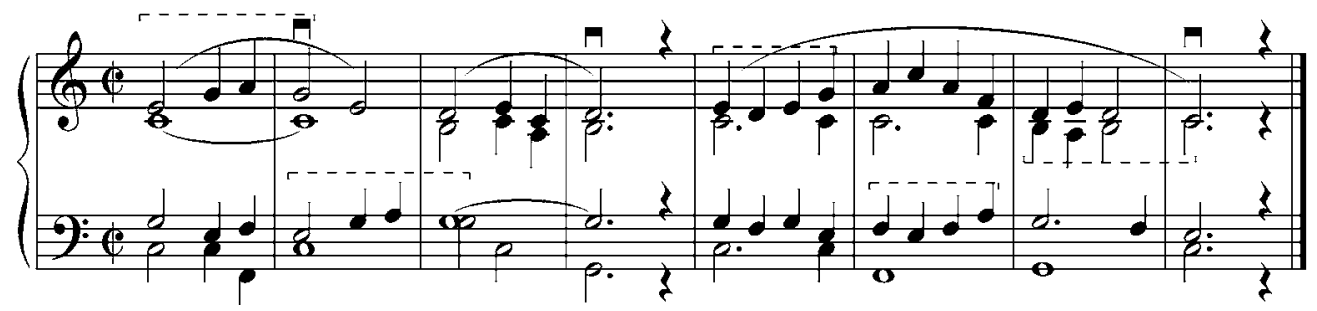

\section{Пример 2 [3, с. 6]}

Мелодический рисунок сопровождающих голосов имеет здесь достаточно четко выраженные тематические функиии и определенные интонаџионные связи с ведушим голосом. Альт в первых двух фразах служит удвоением ведушего голоса, затем эта функџия передается тенору, который поначалу служил педалью.

Ощущение преждевременной тоники в такте 11 преодолевается средствами гармонии $\left(K_{6}\right)$ и ритмической активностью средних голосов в такте 12.
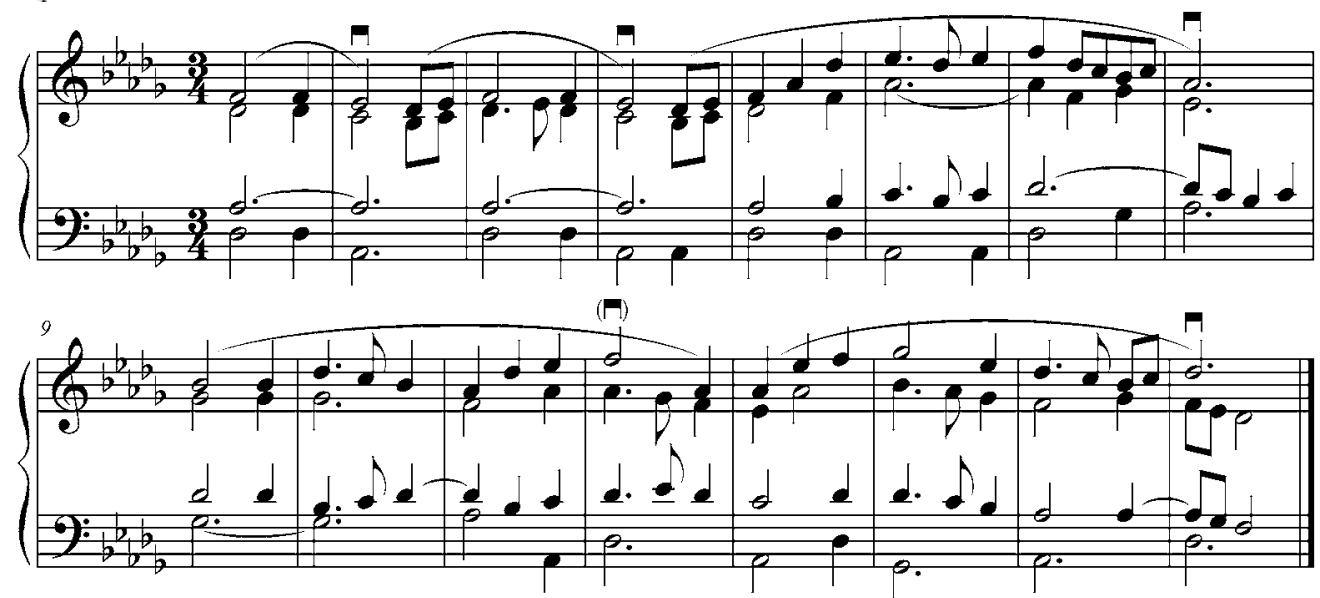


\section{Пример 3 [3, с. 7]}

Сюжет этой короткой мелодии построен на обновлении интонаџионного материала. Важно, что уже в рамках второй фразы в средних голосах удалось подготовить интонаџию заключительной фразы ведушего голоса. В результате и синтаксическая структура, и взаимодействие голосов, и интонаџионная связь разных фраз выстроились в џельную структуру.

Строение вертикали на легких долях тактов 1 и 3 подчиняется логике мелодического движения тенора, удваивающего мелодию на фоне педали в альте.

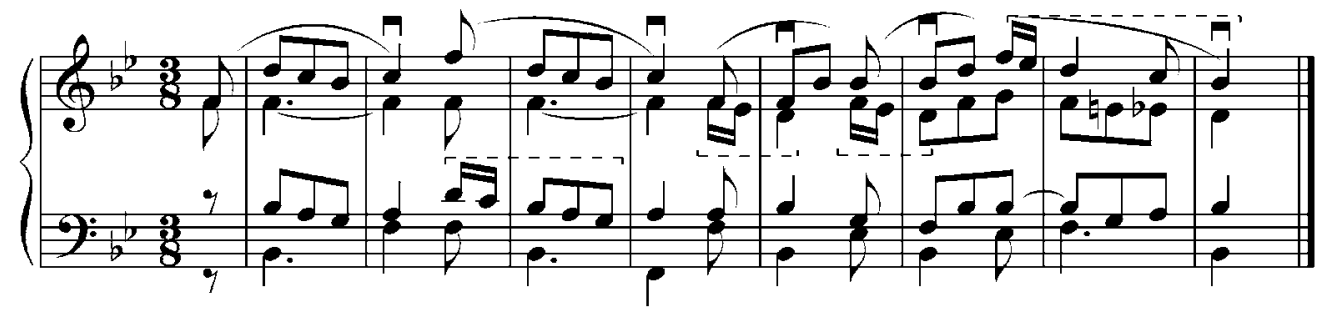

Пример 4 [3, с. 20]

Мелодия задачи содержит всего два тематических элемента, однако их богатые преобразования создают ошушение движения и обновления. Бас интонаџионно связан с мелодией: в первом предложении он образует к ней противодвижение, во втором преимушественно удвоение. Характерная мелодическая фигура в пунктирном ритме образует каденџионную рифму.
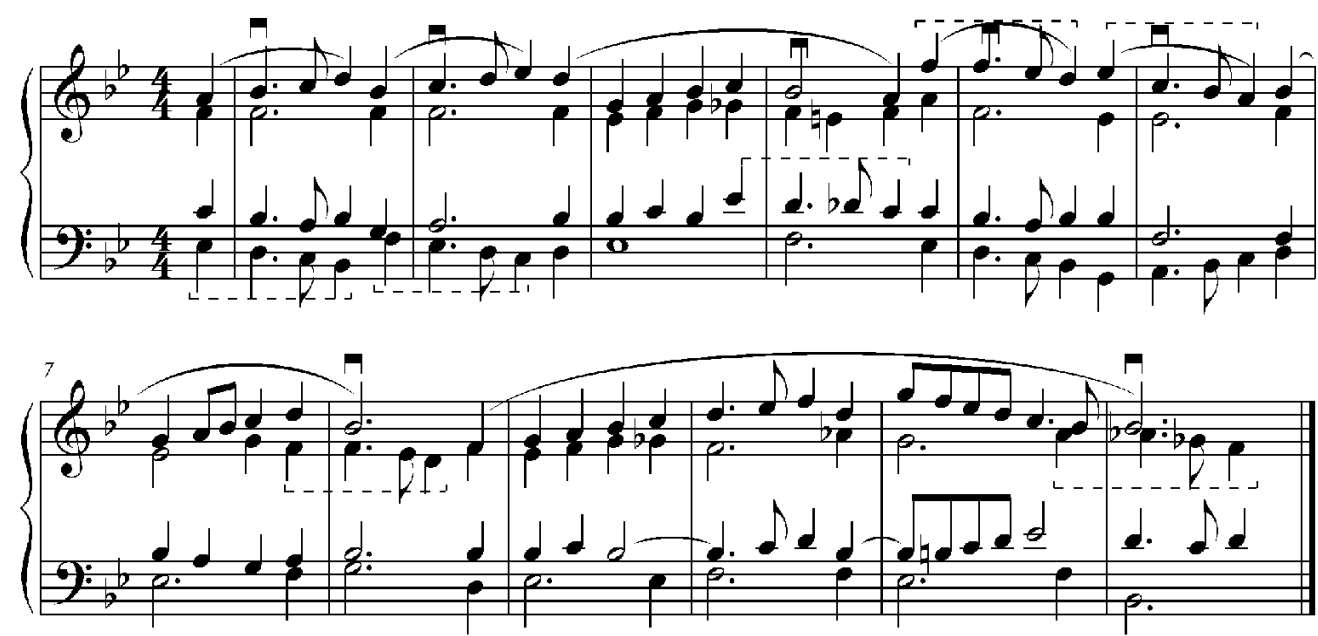


\section{Обращение септаккорда II ступени}

\section{Пример 5 [3, с. 27]}

Очевидна речевая природа основной мелодии, как и вокально-хоровой характер фактуры. Интонаџионное родство соседних фраз базируется на нисходящих разрешениях септимы в обрашениях $\mathrm{II}_{7}$ и сходных с ними задержаниях.

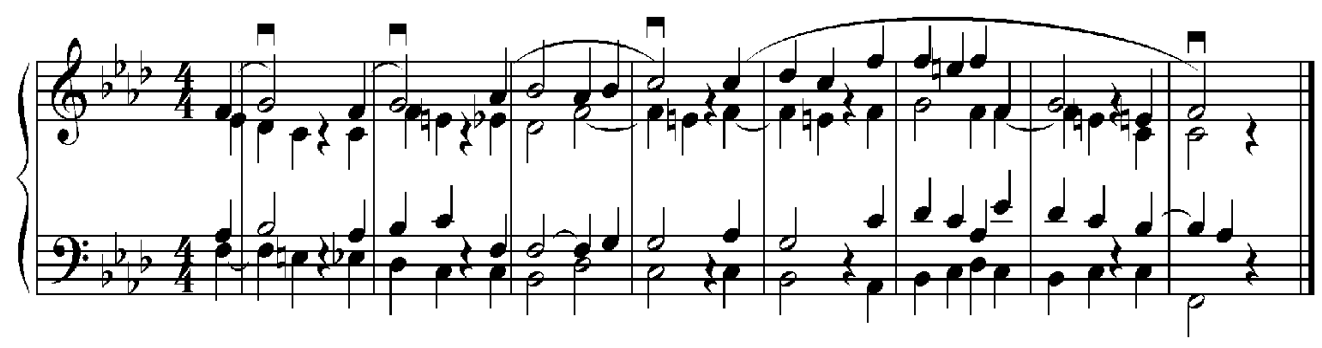

Доминантовый нонаккорд

Пример 6 [2, с. 156]

В основе задачи - џепь звеньев секвенџии с новым устоем в каждом звене. Задержание к терџии $\mathrm{D}_{9}$ обогашает его краску элементом полигармонии.
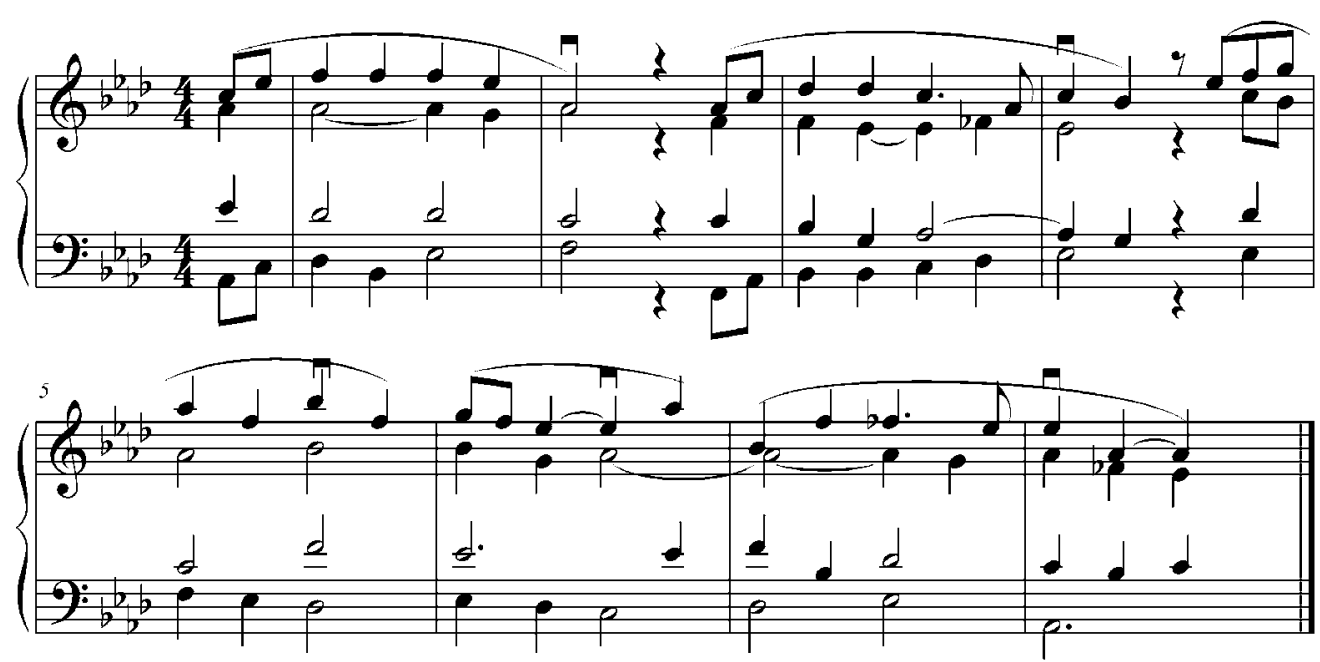

Пример 7 [4, с. 20]

Весьма органично здесь применение гармоний субдоминанты в сопоставлении с тоникой. Особенно выразительно звучит заключительный плагальный оборот. Почти неподвижный рисунок альта делает весьма заметным противодвижение мелодии и баса. 

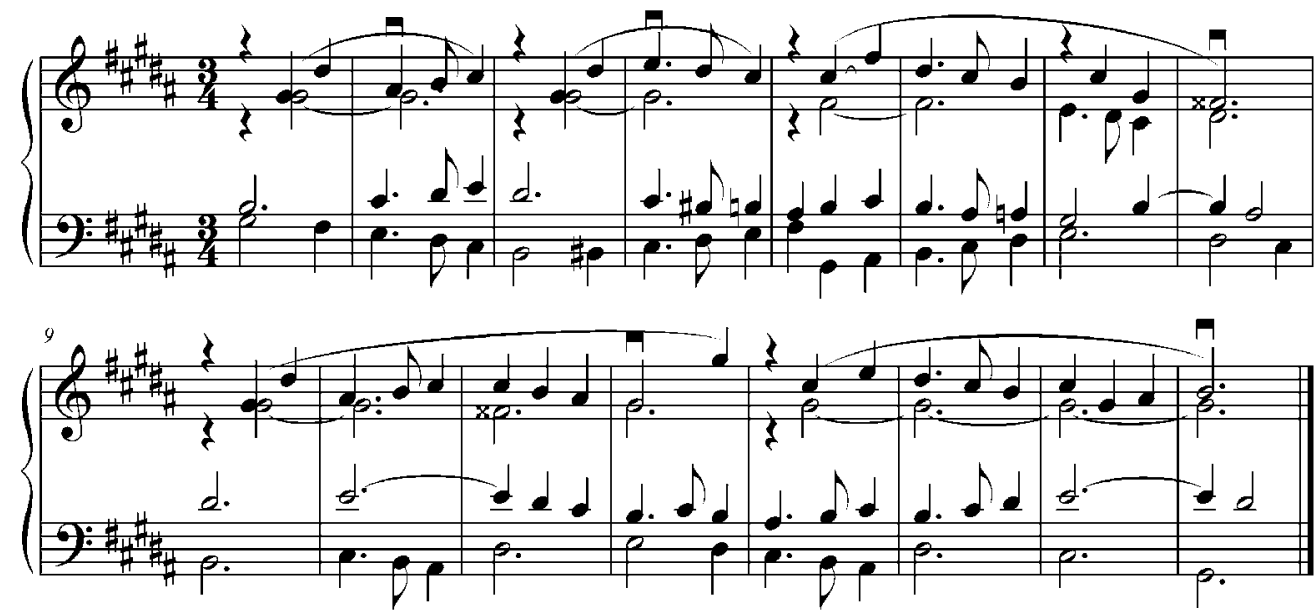

Аккорды двойной доминанты

Пример 8 [3, с. 41]

Чисто речевому типу мелодики задачи соответствует фактура, построенная на весьма взволнованных имитациях. Интонаџии мелодии сначала имитируются тенором и альтом, а во втором предложении к ним подключается и бас.

Активному гармоническому сопряжению гармоний способствует размешением тонической гармонии в легких, нечетных тактах.
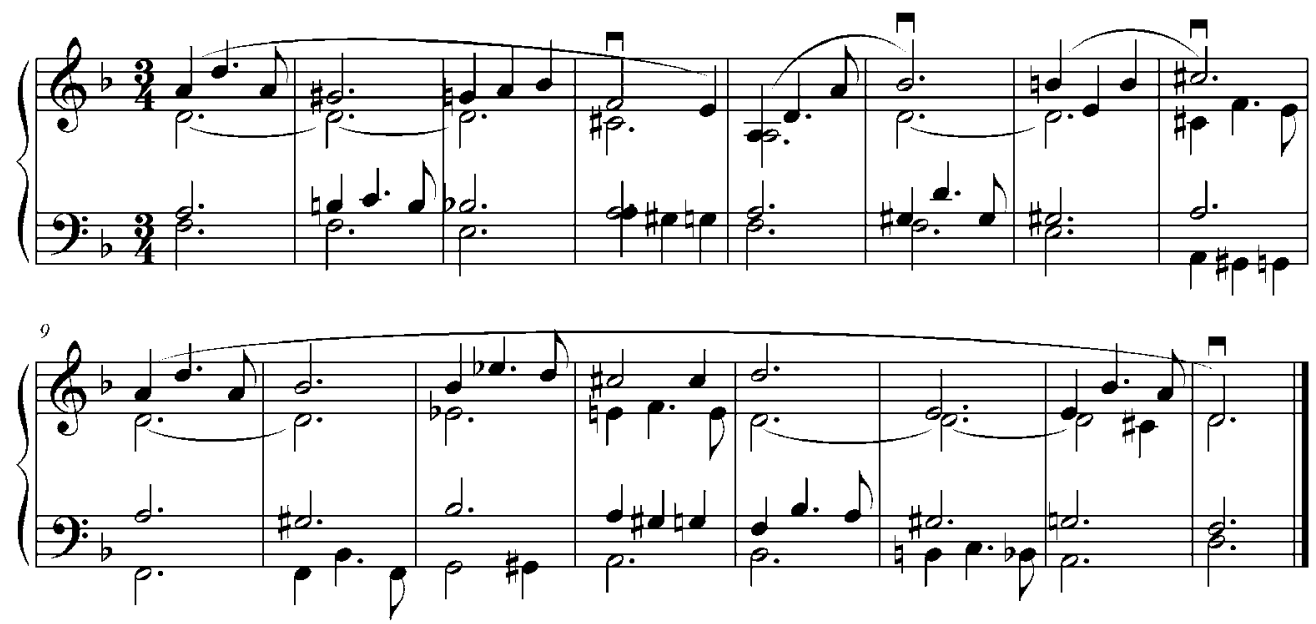

Пример 9 [4, с. 24]

Мелодия задачи, построенная из однотипных интонаџий инструментального характера, весьма удобна для построения имитационной фактуры. Џепь имитащий, с опорой 
на диссонируюшие гармонии, поддерживает непрерывное развертывание материала, приводящее к хроматической кульминаџии в прерванном обороте (такт 8).
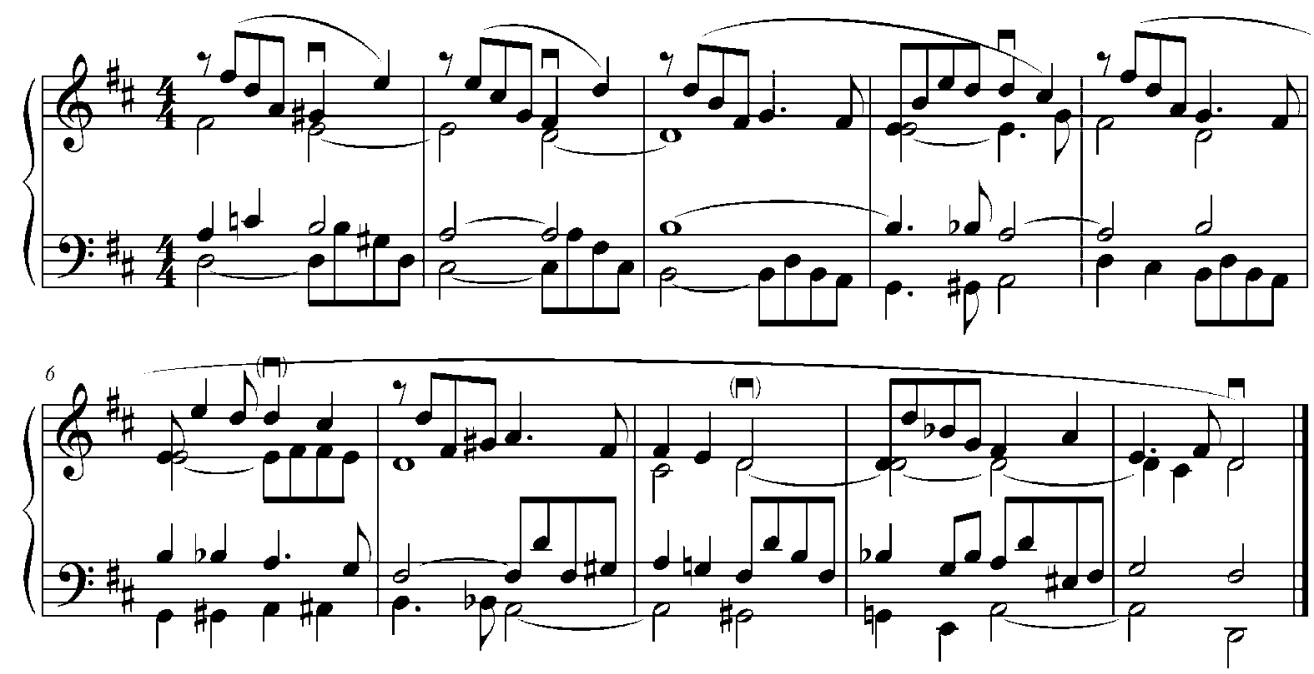

Пример 10 [1, с. 28]
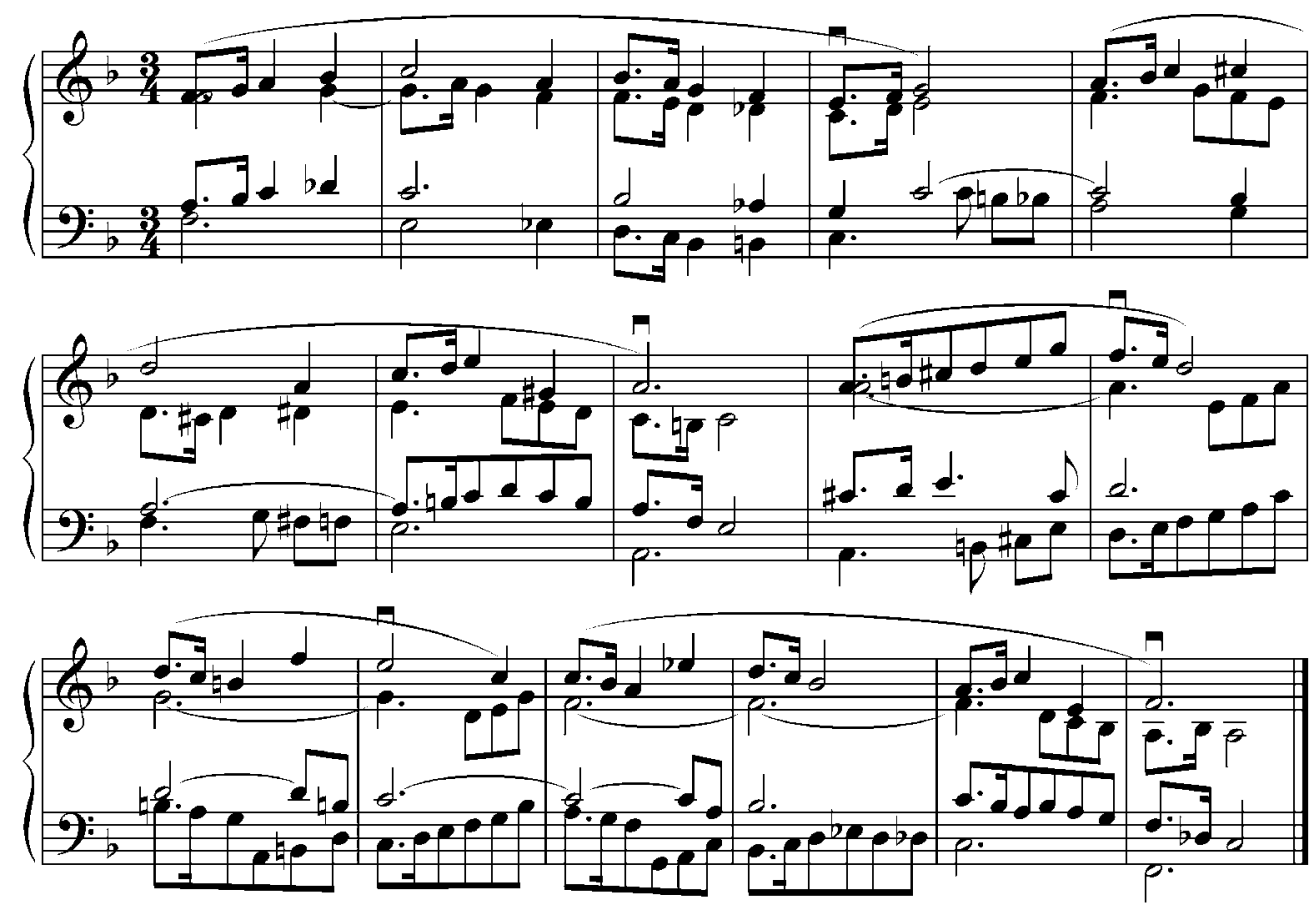
Мелодия задачи имеет прообразом мазурку. Задача написана в двухчастной форме. Характер мазурки, с ее типичными акџентами на второй доле такта и дроблением третьей доли, хорошо раскрыт в гармоническом сопровождении.

Вторая часть, передаюшая парный характер танџа, построена в виде канонической секвениии, в первом звене которой участвуют крайние голоса, а в остальных двух иниџиатива переходит к нижней паре.

\section{Пример 11 [1, с. 33]}

Задача построена на материале хорального склада. Ее начало с кадансового квартсекстаккорда («запрешенное» школьными правилами), как и прерванный оборот во втором такте, выглядят здесь весьма органично, так как оттягивают появление тонической гармонии вплоть до каденџии первого предложения.

Побочные тональности в развивающем разделе представлены своими тониками, что также естественно, так как они уводят от главной тоники.

Началу репризы предшествует ход баса, повторяюший характерный рисунок начала темы, удвоенный тенором и предваряюший возврашение кадансового квартсекстаккорда. Мелодия последнего двутакта представляет развитие и завершение исходной интонаџии темы.
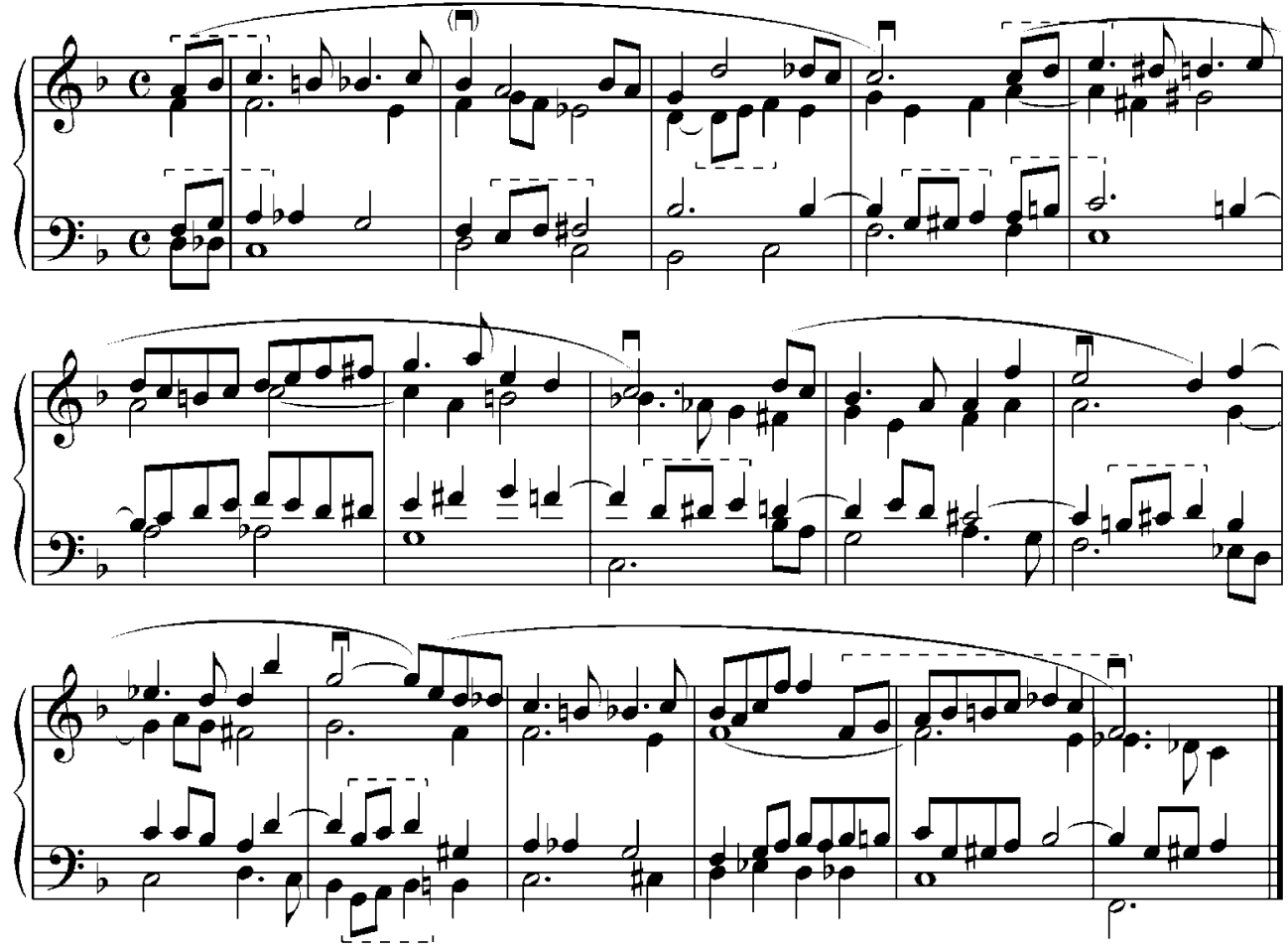


\section{Приготовленное задержание}

Пример 12 [2, с. 267]

Структура мелодии - период из трех предложений $(4+1+1+2+4)$. Здесь хорошо видно, что именно задержания способны подчеркивать вес тактов.

Возникаюшие на слабых долях тактов «застои» преодолеваются плавным движением сопровождаюших голосов.

В конџе второго предложения модуляџия в тональность третьей (низкой) ступени. В третьем предложении движение в сторону низких ступеней достигает кульминаџии на «неаполитанской гармонии с ярким задержанием.
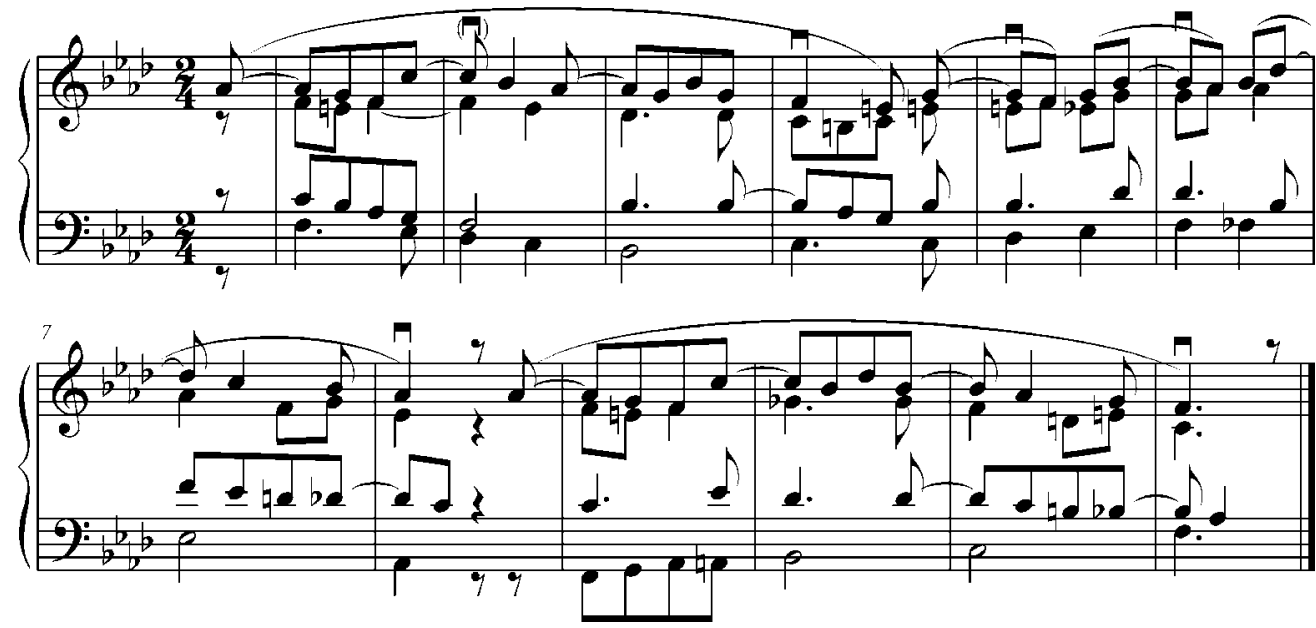

Диатонические проходящие звуки

Пример 13 [2, с. 280]

Весьма скупая ткань начальных тактов обеспечивает сбережение тонической функџии, к которой постоянно возврашается ведуший голос. Партия тенора построена на контрапунктирующей интонаџии, которая продолжается во втором предложении и создает каденџионную рифму.

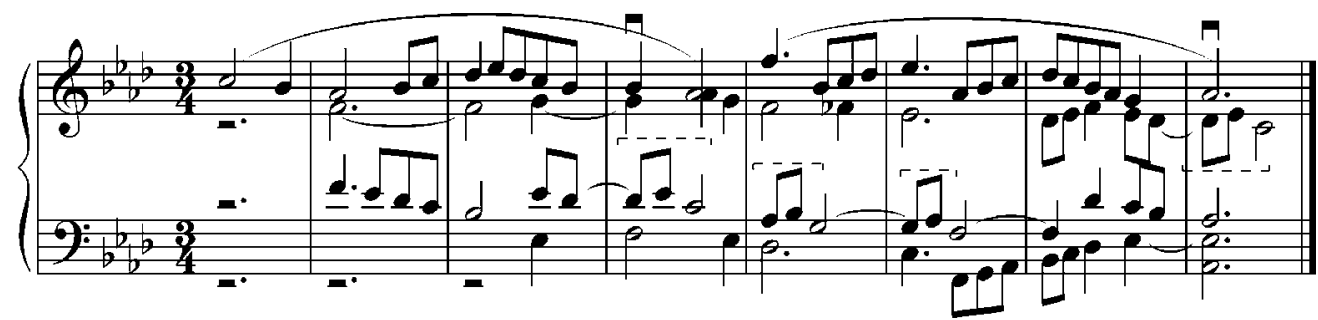




\section{Пример 14 [4, с. 48]}

Четкая синтаксическая структура мелодии, основанная на развитии исходного ядра, позволяет находить разнообразные формы ее отражения в виде свободных имитаций в сопровождаюших голосах.

Бас преимушественно образует противодвижение к ведушему голосу. Альт — голос чисто гармонический.
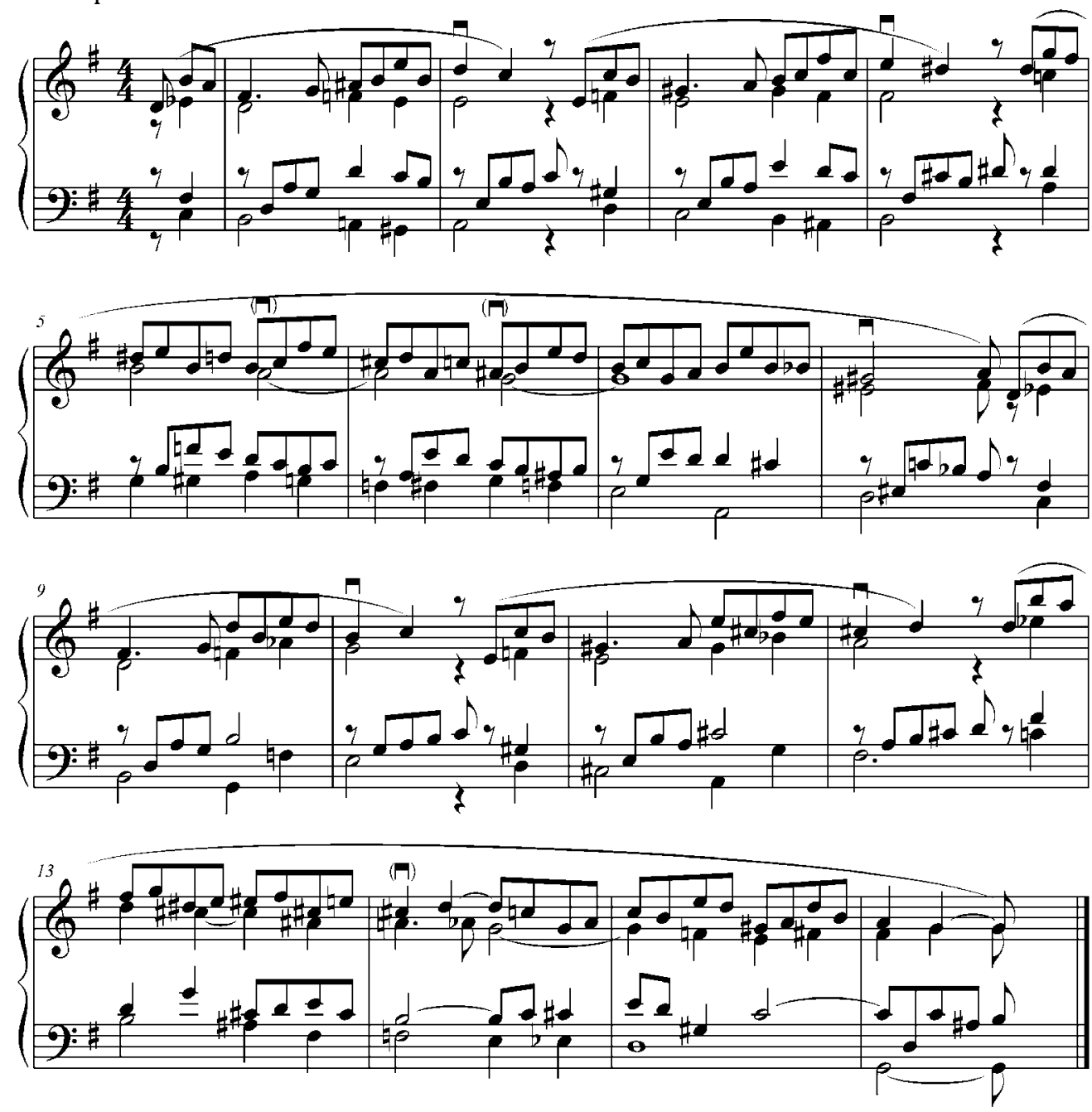

Вспомогательные звуки и созвучия

Пример 15 [2, с. 304]

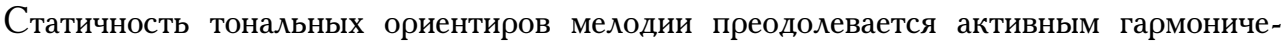
ским сопровождением, построенным на преодолении устойчивости с помощью побочной 
доминанты, звучашей в звукоряде мелодического мажора. Гармоническая тоника появляется лишь в последнем такте задачи, вновь, как в ядре темы, в звукоряде мелодического мажора. Дополнительное средство, поддерживающее постоянное движение - имитации әлементов темы в сопровождаюших голосах.
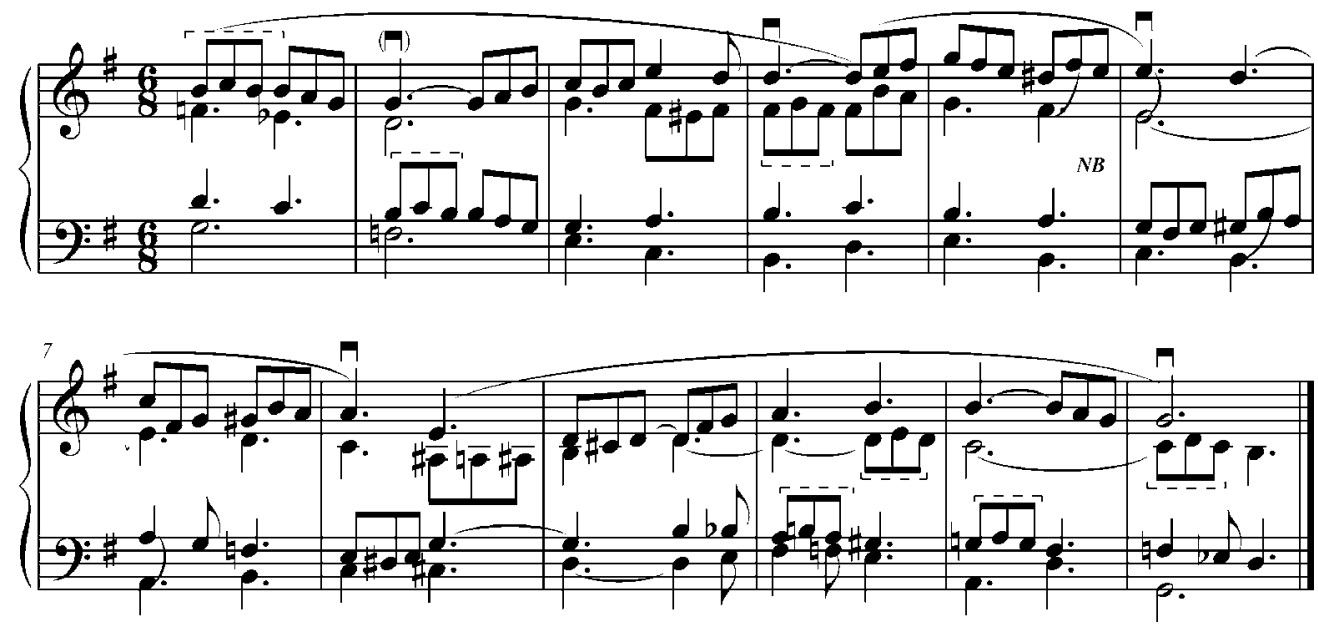

Хроматические проходящие звуки и созвучия

Пример 16 [2, с. 298]

Основа фактуры - удвоение ведушего голоса и баса реальными дублировками, дополненное имитацией элементов темы.
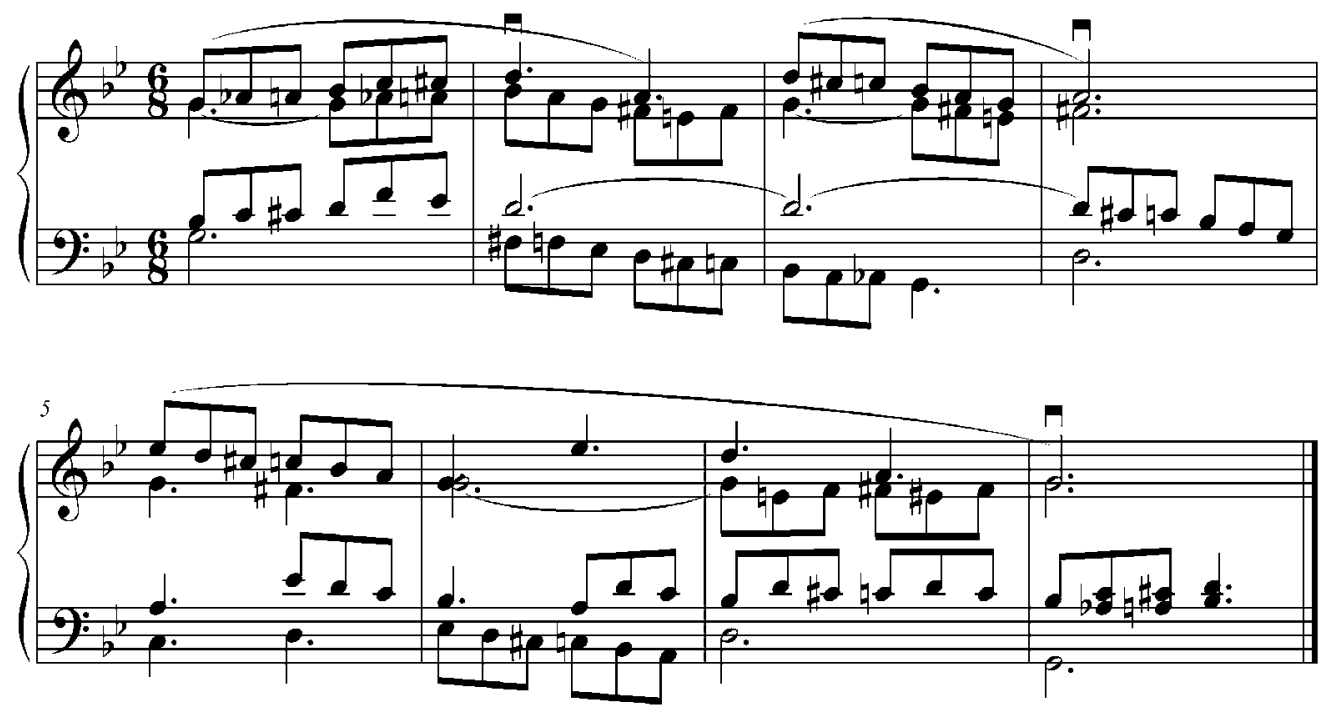


\section{Пример 17 [2, с. 319]}

Интонаџионный материал задачи имеет выраженную речевую жанровую природу. Солирующая мелодия противопоставлена трем сопровождающим голосам.

Все три предложения имеют структуру суммирования $-1+1+2$. В двух первых предложениях точки покоя преодолены диссонирующей гармонией и нисходящим басом. Заключительный каданс «вспоминает» ядро темы.
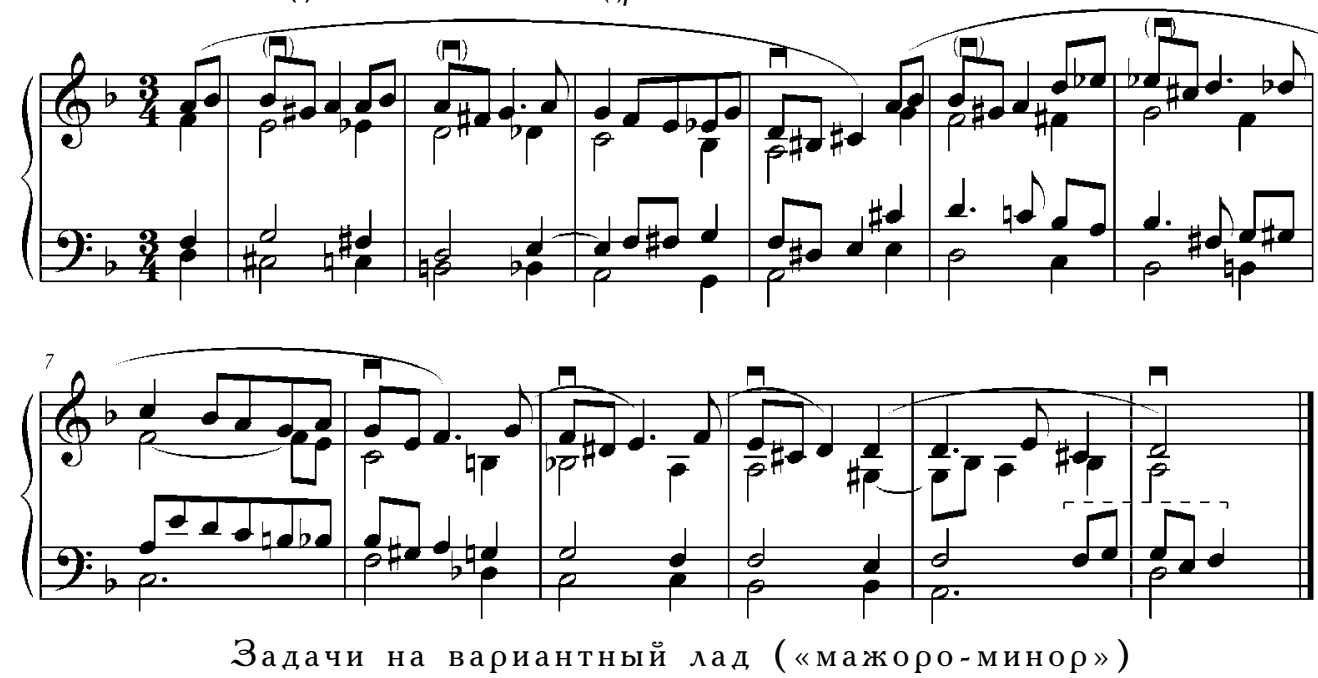

Пример 18 [2, с. 366]

Мелодия по своим жанровым признакам близка менуэту. В первом предложении на тонической педали в басу развертывается диалог сопрано и тенора с имитаџией заключительной интонаџии. Во втором предложении такой же диалог сопрано и баса.

Вторая часть содержит секвенџию в темной одноименной тональности и ее параллели. Репризное построение возврашает светлый колорит главной тональности.
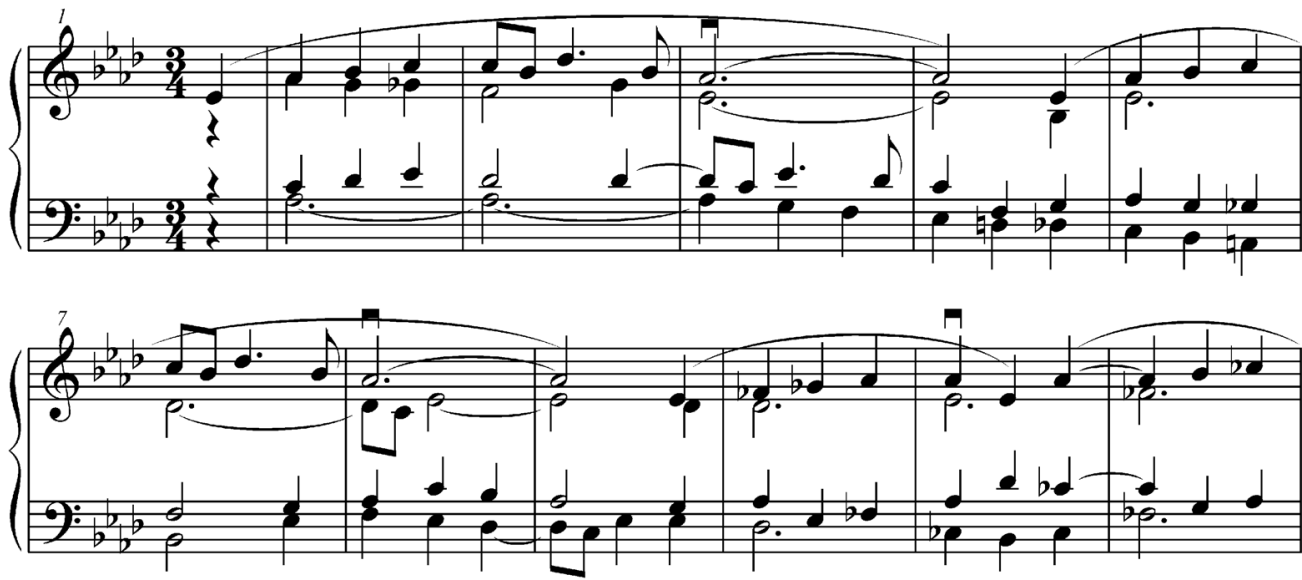


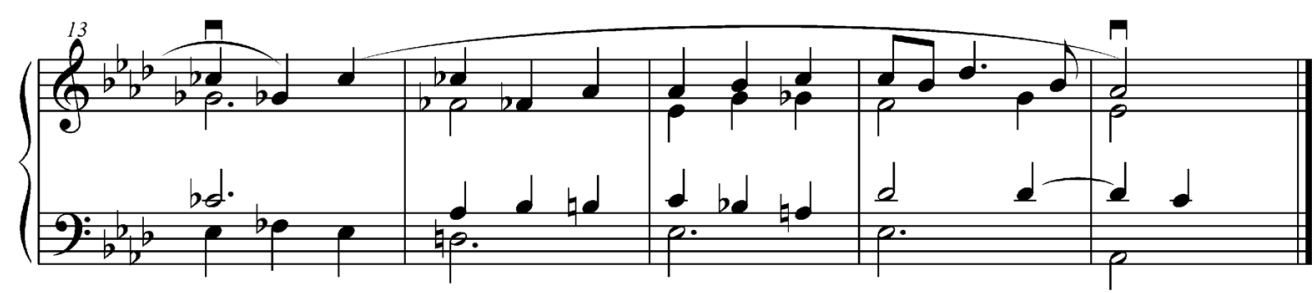

Альтераџия доминантовых гармоний

\section{Пример 19 [2, с. 327]}

Применение альтераџии создает достаточное разнообразие гармонических красок, позволяюшее сопоставить аккорды различной модальной природы. В данном решении особый интерес представляет сопоставление гармоний цुелотонных с чистодиатоническими и хроматическими.

Гармонический оборот в начальной фразе содержит эллиптический оборот — џепочку септаккордов в верхне-квартовом соотношении, где гармония первого такта - нотируется как побочная доминанта к субдоминанте и разрешается в обрашение альтерированного вводного септаккорда, имитируя последовательность двух септаккордов в верхнеквартовом соотношении.

Этот оборот ложится в основу третьего предложения, построенного как продолжение доминантовой џепи из начального оборота.
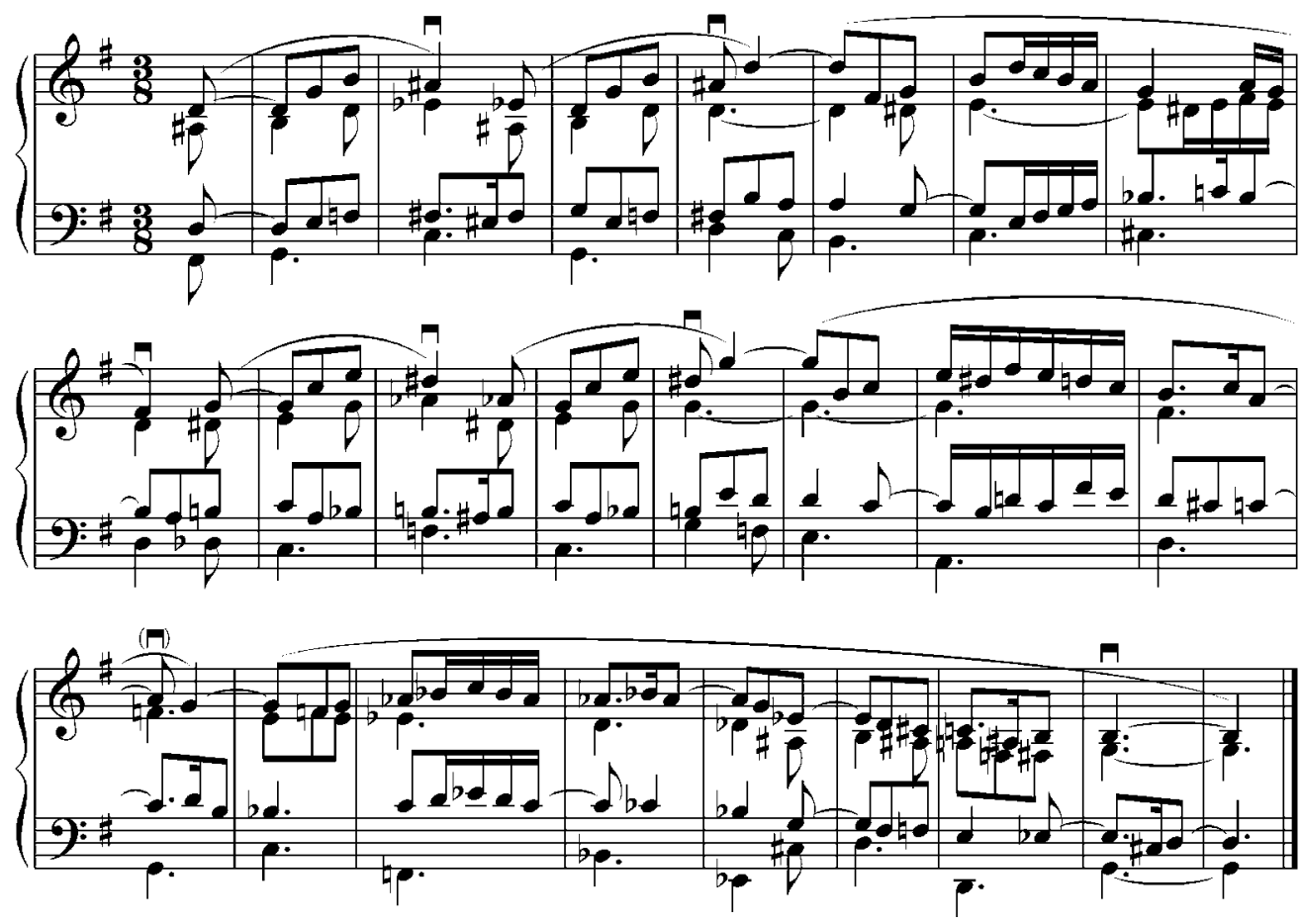
Пример 20 [1, с. 116]

Задача написана в двухчастной репризной форме. Тональный план первого периода содержит большетерџовый ряд мажорных тональностей - F-dur, A-dur и Des-dur. Середина также построена на терџовом ряде тональностей, но уже минорных, родственных главной: b-moll и d-moll, подводящих к репризе в F-dur.

Интонаџионный материал гармонической ткани можно назвать моноинтонационным построенным на развитии исходной интонации, которая проходит во всех голосах ткани, как в прямом, так и в обрашенном виде, и во всех разделах формы. Интонаџия начальной фразы образует и удвоения ведушего голоса, и имитирует его, и образует противодвижение, как в исходном ритме, так и в увеличении.
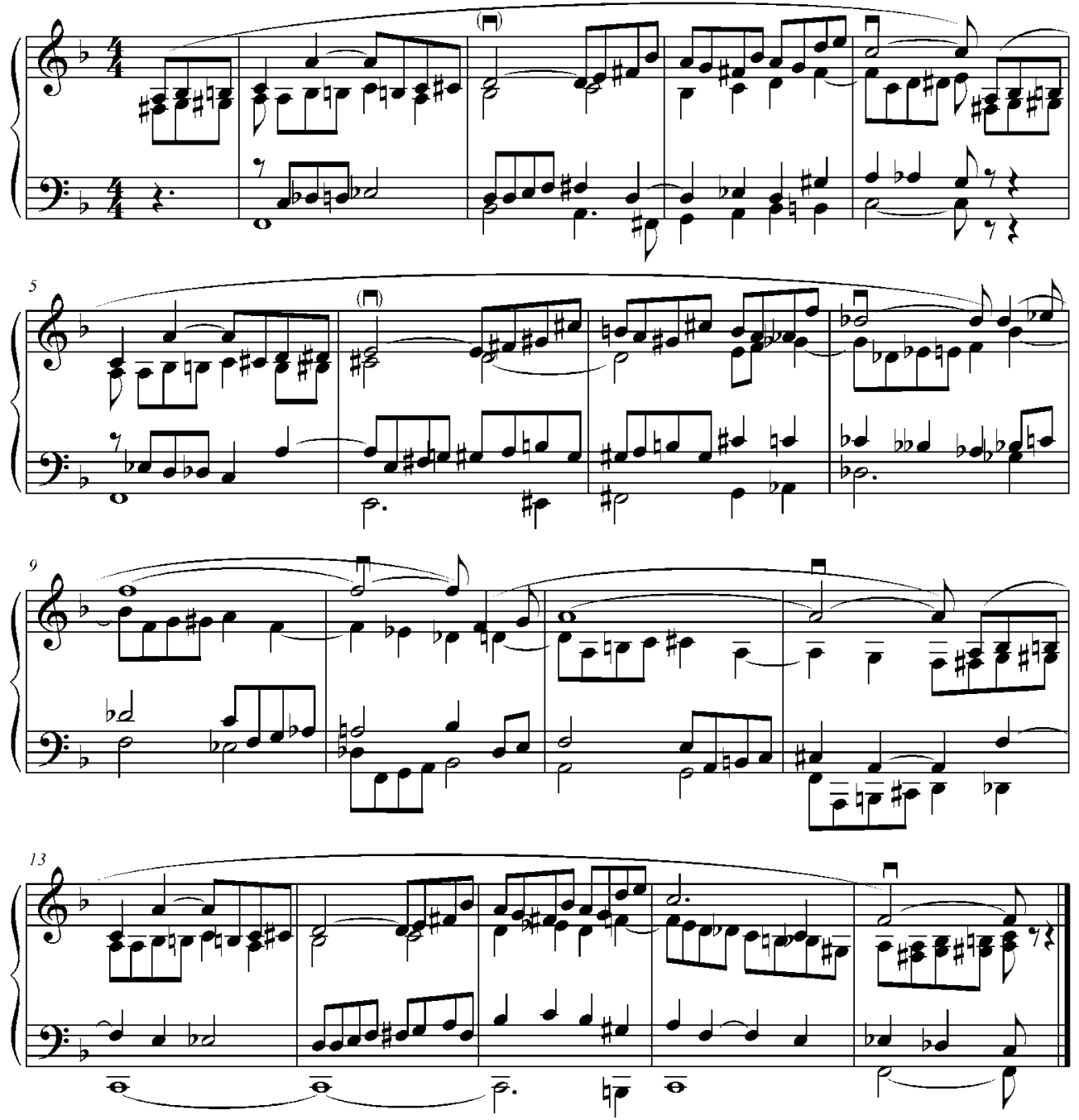


\section{ЛИТЕРАТУРА}

1. Берков В., Степанов А. Задачи по гармонии. М.: Музыка, 1973. 128 с.

2. Дубовский И., Евсеев С., Способин И., Соколов В. Учебник гармонии. М.: Музыка, 1969. $454 \mathrm{c.}$

3. Кириллова В., Наумов А., Степанов А., Таранущенко В. Практические задания к курсу гармонии / ГМПИ им. Гнесиных. М.: [Б. и.], 1976. 43 с.

4. Мясоедов $A$. Задачи по гармонии. 4-е изд. М.: Музыка, 1994. 110 с.

5. Мутли $A$. Мелодические функџии голосов многоголосной музыки // Проблемы организации музыкального произведения: Сб. науч. тр. / МГК им. П.И. Чайковского. М.: [Б. и.], 1979. 147 с.

6. Мутли А. Сборник задач по гармонии: Учебное пособие для музыкальных училищ и консерваторий. 7-е изд. М.: Музыка, 1986. 147 с.

7. Середа В.П. Загадки гармонической ткани. «Новая модальность» в романсах С. Рахманинова.Тамбов: Издательство Першина Р. В., 2013. 80 с.

8. Середа В.П. Как оживлять звуки, как открывать музыку. Логика классической тональной системы. М.: Классика-XXI, 2011. 196 с.

9. Середа В.П. О ладе в музыке и «разладе» в теории музыки: размышления, обрашенные к педагогам-музыкантам и любителям музыки. М.: Классика-XXI, 2010. 110 с.

\section{$T, P 7$ Российское отделение Европейской Ассоциации педагогов фортепиано («ЭПТА»)}

объявляет о подписке на журнал

\section{ФОРТЕПИАНО}

$$
\text { на } 2 \text {-е полугодие } 2014 \text { года }
$$

В журнале, адресованном педагогам фортепиано

всех уровней образования -

от школ до вузов, содержатся самые разнообразные материалы по проблемам исполнительства и педагогики

(в т. ч. методические рекомендации, а также необходимая информация о предстоящих региональных и международных конкурсах).

Подписной индекс журнала - 34207

по Объединенному (зеленому) каталогу «Пресса России» 